\title{
Pengembangan Media Pembelajaran Digital Sistem Distribusi Energi Listrik Berbasis Pemahaman Konsep bagi Mahasiswa Program Studi S1 Teknik Elektro Di Universitas Negeri Malang
}

\author{
David Anggara Putra ${ }^{1}$, Yuni Rahmawati ${ }^{2}$, Hari Putranto ${ }^{3}$ \\ ${ }^{1,2,3}$ S1 Pendidikan Teknik Elektro, Jurusan Teknik Elektro, Fakultas Teknik, Universitas Negeri Malang \\ davidanggaragara@gmail.com \\ yuni.rahmawati.ft@um.ac.id \\ hari.putranto.ft@um.ac.id
}

\begin{abstract}
Abstrak - Tujuan penelitian dan pengembangan ini adalah: (1) Merancang dan membuat media pembelajaran digital sistem distribusi energi listrik berbasis pemahaman konsep pada pembelajaran energi baru terbarukan di TE UM; (2) Merancang dan membuat simulasi sistem distribusi energi listrik berbasis pemahaman konsep pada pembelajaran energi baru terbarukan di TE UM; (3) Menguji kelayakan media pembelajaran digital sistem distribusi energi listrik berbasis pemahaman konsep pada pembelajaran energi baru terbarukan di TE UM. Pengembangan ini menggunakan model penelitian ADDIE dengan lima tahap penelitian dan pengembangan. Uji kelayakan bahan ajar dilakukan oleh 2 (dua) dosen ahli Teknik Elektro, mahasiswa S1 TE angkatan 2015 dan mahasiswa S1 TE angkatan 2016 untuk megevaluasi kelayakan media pembelajaran digital dan simulasi menggunakan instrumen berupa angket. Hasil penelitian menunjukkan bahwa tingkat kelayakan media pembelajaran digital energi terbarukan tentang sistem distribusi tenaga listrik pembangkit energi terbarukan memperoleh persentase sebesar 83,4\% dari 2 (dua) dosen ahli yang artinya produk layak digunakan dengan sedikit revisi, 86\% dari 10 (sepuluh) mahasiswa S1 TE 2015 yang artinya produk sangat layak untuk digunakan, sedangkan dari mahasiswa S1 TE 2016 memperoleh 88\% yang artinya produk sangat layak digunakan tanpa ada revisi lagi.
\end{abstract}

Kata kunci: Media Pembelajaran, Distribusi, Pemahaman Konsep, Energi Baru dan Terbarukan.

Abstract - Research and development objectives are: (1) Designing and making digital learning media distribution system based understanding of the concept of electric energy on learning new renewable energy in TE UM; (2) Designing and making the electrical energy distribution system simulation based on the understanding of the concept of learning a new renewable energy in TE UM; (3) Examine the feasibility of digital learning media electric energy distribution system based understanding of the concept of the learning of new renewable energy in TE UM. This development model ADDIE research with five (5) stages of research and development. Test the feasibility of teaching materials made by two (2) Electrical Engineering expert lecturers, student TE 2015 and student TE 2016 for a feasibility evaluated a digital learning media and simulations using questionnaire instrument. Research results suggest that levels of digital learning media are renewable energy about distribution system of renewable energy plants a percentage as $83,4 \%$ from two lecture which means it is worth using with a little revision, $86 \%$ from ten students TE 2015 which means that products are perfectly worth to use, whereas from student TE 2016 get $88 \%$ which means that products are perfectly worth to use without revision again.

Keywords: Learning media, Distribution, Concept Training, Renewable Energy. 


\section{PENDAHULUAN}

Dewasa ini penggunaan energi baru dan terbarukan menjadi isu utama di berbagai negara, tujuannya adalah untuk menjaga keberlangsungan energi. Untuk mengatasi kebutuhan energi listrik dimasa yang akan datang, penggunaan energi baru dan terbarukan sangat penting terhadap sistem yang berkelanjutan, karena sifat energi baru dan terbarukan dapat digunakan dalam rentang waktu yang lama dan mudah didapatkan tanpa menunggu waktu yang lama [1]. Sedangkan di Indonesia sendiri mulai gencar pemanfaatan energi baru dan terbarukan untuk menjaga komposisi bauran energi (energy mix) pembangkit tetap optimal. Upaya ini ditempuh melalui pengesahan Rencana Usaha Penyediaan Tenaga Listrik (RUPTL) PT. Perusahaan Listrik Negara (PLN) Persero 2018-2027. Dalam RUPTL tersebut, pemerintah telah menetapkan target bauran energi pembangkit sampai dengan akhir 2025 untuk Energi Baru Terbarukan (EBT) dari 12,4\% menjadi 23,0\% [2].

Seiring dengan meningkatnya pemanfaatan energi baru dan terbarukan dalam bidang pembangkitan energi listrik, dibutuhkan regenerasi sumber daya manusia untuk mengelolanya. Regenerasi sumber daya manusia dapat dilakukan melalui sistem pendidikan untuk mencapai suatu keahlian atau kompetensi tertentu. Dalam penerapannya pendidikan memerlukan beberapa perangkat pembelajaran untuk dapat berjalan, diantaranya ada media dan bahan ajar yang dapat digunakan sebagai sarana untuk memahami konsep dari kompetensi atau keahlian yang dipelajari.

Pemahaman berasal dari kata "paham" yang menurut Kamus Besar Bahasa Indonesia (KBBI) [3] berarti mengerti dengan tepat. Sedangkan menurut Smith dan Sandra [4] konsep merupakan pengetahuan yang diperoleh dari pengalaman belajar sebelumnya, membaca buku, internet, serta pengalaman di lingkungannya. Sehingga dapat diambil kesimpulan bahwa pemahaman konsep merupakan pengertian yang benar tentang pengetahuan yang diperoleh dari pengalaman selama hidupnya. Konsep merencanakan pemasangan sumber energi baru dan terbarukan ke dalam jaringan energi listrik digunakan untuk melihat keandalan dari suatu sistem jaringan. Dalam merencanakan pemasangan sumber energi baru dan terbarukan ke dalam jaringan listrik digunakan analisa aliran beban. Analisa aliran beban penting untuk perencanaan, operasi ekonomi, penjadwalan dan perubahan utilitas daya.

Salah satu matakuliah yang mempelajari tentang instalasi tenaga sumber energi baru terbarukan ke dalam jaringan listrik adalah matakuliah Energi Baru dan Terbarukan yang ditempuh oleh mahasiswa program studi S1 Teknik Elektro (S1 TE) jurusan Teknik Elektro Universitas Negeri Malang (TE UM). Standar kompetensi yang harus dikuasai oleh mahasiswa diantaranya adalah mampu memperjelas prinsip kerja konversi energi baru dan terbarukan yang ditinjau dari aspek teknis, ekonomis, finansial, sosial-budaya dan lingkungan. Dari hasil wawancara dengan dosen pengampu matakuliah Energi Baru dan Terbarukan pada bulan Desember 2018, dapat disimpulkan bahwa permasalahan yang terjadi dalam proses pembelajaran ialah masih belum tersedianya media pembelajaran berupa alat peraga atau trainer untuk menunjang kegiatan pembelajaran yang berlangsung. Disisi lain menurut hasil wawancara dengan beberapa mahasiswa S1 TE UM angkatan 2015 yang telah menempuh matakuliah Energi Baru dan Terbarukan, kompetensi yang diperoleh dari pembelajaran di matakuliah Energi Baru dan Terbarukan berfokus pada prinsip konversi energi dan belum cukup untuk mengimbangi pesatnya perkembangan dibidang pembangkitan energi listrik energi baru terbarukan.

Berdasarkan uraian kondisi pembelajaran dan permasalahan yang telah dipaparkan, untuk meningkatkan pemahaman konsep mahasiswa S1 TE UM dibutuhkan bahan ajar yang dapat memperagakan fenomena dan dapat dengan mudah digunakan mahasiswa secara personal, maka ditetapkan judul skripsi yaitu "Pengembangan Media Pembelajaran Digital Sistem Distribusi Energi Listrik Berbasis Pemahaman Konsep Pada Pembelajaran Energi Baru dan Terbarukan Bagi Mahasiswa Program Studi S1 Teknik Elektro Jurusan Teknik Elektro di Universitas Negeri Malang".

Alasan mengapa digunakan media pembelajaran digital karena jauh lebih efektif dan efisien digunakan dalam pembelajaran. Media pembelajaran digital termasuk dalam media pembelajaran berbasis komputer, dimana hanya memerlukan komputer dan aplikasi untuk menjalankan media pembelajaran tersebut. Media pembelajaran digital ini nantinya akan memanfaatkan aplikasi ETAP 12.6.0 sebagai platform untuk menjalankan simulator sistem distribusi energi listrik. Diharapkan nantinya mahasiswa dapat menggunakan media pembelajaran digital dimasing-masing komputernya. Disamping itu juga akan disediakan modul digital untuk media pembelajaran digital sistem distribusi energi listrik agar memudahkan dalam melakasanakan pembelajaran menggunakan media digital baik secara bekelompok dikelas maupun secara mandiri dirumah.

\section{METODE}

Penelitian dan pengembangan ini berguna untuk mengembangkan bahan ajar yang bisa digunakan sebagai penunjang proses pembelajaran pada pembelajaran Energi Baru dan Terbarukan. Selain bisa digunakan didalam kelas, media pembelajaran digital ini bisa digunakan diluar kelas sebagai sumber belajar mandiri mahasiswa. Tidak hanya itu, media pembelajaran digital ini bisa juga digunakan pada matakuliah lain yang memiliki materi yang sama atau berhubungan, seperti matakuliah Sistem Pembangkit Terdistribusi, Sistem Transmisi dan Distribusi dan Analisis Sistem Tenaga yang juga ditempuh oleh mahasiswa S1 PTE dan D3 Elektro. Penggunaan media pembelajaran digital ini mempermudah mahasiswa memahami materi tentang sistem distribusi tenaga listrik pada pembangkit listrik energi baru dan terbarukan karena mahasiswa akan diperkenalkan dengan 
masing-masing komponennya walaupun dalam bentuk maya, serta dapat melakukan penyetelan secara mandiri dengan panduan modul digital.

Model penelitian dan pengembangan yang digunakan untuk mengembangkan media pembelajaran digital adalah model penelitian dan pengembangan ADDIE. Model tersebut dipilih sebagai dasar untuk mengembangkan produk media pembelajaran digital ini karena langkah-langkahnya yang sistematis sesuai dengan kebutuhan yang akan digunakan, serta aturan yang baik dan fleksibel untuk digunakan mengembangkan media pembelajaran digital sistem distribusi tenaga listrik pada pembangkit listrik energi baru dan terbarukan.

Model penelitian dan pengembangan ADDIE terdiri dari 5 tahap, yaitu: (1) Analisis kebutuhan media pada pembelajaran matakuliah Energi Baru dan Terbarukan; (2) Desain Media pembelajaran berupa modul digital dan simulator sistem distribusi tenaga listrik pada pembangkit dengan sumber energi baru dan terbarukan; (3) Pengembangan modul digital dan simulator sistem distribusi tenaga listrik pada pembangkit dengan sumber energi baru dan terbarukan; (4) Implementasi modul digital dan simulator sistem distribusi tenaga listrik pada pembangkit dengan sumber energi baru dan terbarukan; (5) Evaluasi.

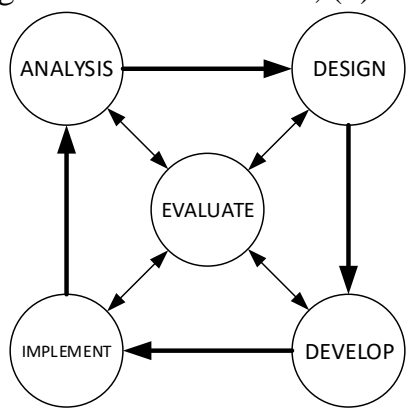

Gambar 1. Model Penelitian dan Pengembangan ADDIE

\section{Prosedur penelitian dengan model ADDIE:}

\section{Analysis}

Analisis adalah suatu langkah awal dalam prosedur pengembangan ADDIE. Langkah awal yang dilakukan adalah melakukan observasi langsung kepada mahasiswa Prodi S1 TE angkatan 2015 yang sudah menempuh matakuliah Energi Baru dan Terbarukan untuk mengetahui potensi dan masalah yang terjadi dalam proses pembelajaran. Selain kepada mahasiswa, observasi juga dilakukan kepada dosen pengampu matakuliah Energi Baru dan Terbarukan. Melalui observasi yang dilakukan diharapkan mendapatkan gambaran tentang keadaan yang selama ini terjadi, media apa saja yang selama ini digunakan dan proses pembelajaran yang tepat digunakan dalam matakuliah Energi Baru dan Terbarukan.

Melalui observasi yang dilakukan pada mahasiswa S1 TE 2015, kegiatan pembelajaran masih berisi ceramah, diskusi, penugasan dan presentasi oleh mahasiswa. Dengan demikian peneliti ingin merancang media pembelajaran berupa media pembelajaran digital agar kegiatan pembelajaran lebih menarik. Tidak hanya itu, masalah yang bisa dijadikan potensi yaitu lambatnya mahasiswa S1 TE memahami materi sistem distribusi tenaga listrik pada pembangkit listrik energi baru dan terbarukan, akibat tidak adanya media yang dapat meningkatkan pemahaman dalam proses pembelajaran. Masih belum adanya media yang dapat digunakan untuk belajar mandiri yang juga menjadi salah satu faktor kurang maksimalnya mahasiswa dalam memahami materi yang disampaikan.

Selain masalah atau kendala seperti dijelaskan diatas, dari kegiatan wawancara dan observasi, diperoleh potensi yaitu terdapat LCD proyektor disetiap kelas yang ada dijurusan Teknik Elektru Universitas Negeri Malang. Dengan demikian sangat memungkinkan untuk menampilkan media pembelajaran digital melalu LCD proyektor tersebut. Potensi lain yaitu dosen dan seluruh mahasiswa S1 Teknik Elektro memiliki laptop pribadi sehingga media pembelajaran digital bisa dioperasikan dengan laptop masing-masing.

\section{Design}

Beberapa kegiatan yang dilakukan pada tahap desain meliputi desain simulator dan desain modul digital. Masingmasing tahapan desain dijelaskan sebagai berikut:

\section{a. Desain Simulator}

Dalam mendesain atau merancang simulator sistem distribusi tenaga listrik pada pembangkit dengan sumber energi baru dan terbarukan menggunakan software ETAP 12.6.0. Software ETAP 12.6.0 digunakan sebagai media dalam pembuatan rangkaian sekaligus sebagai media penyetelan rangkaian.

Pada pembangkit listrik tenaga sinar matahari listrik yang dihasilkan ialah listrik arus searah (DC), sedangkan listrik dari jaringan PLN sendiri merupakan listrik arus bolak-balik (AC). Untuk itu dibutuhkan beberapa perangkat tambahan agar energi listrik yang dihasilkan pembangkit listrik tenaga surya agar dapat dihubungkan dengan jaringan PLN. Lebih jelasnya ditunjukkan pada Gambar 2, Gambar 3, Gambar 4 dan Gambar 5.

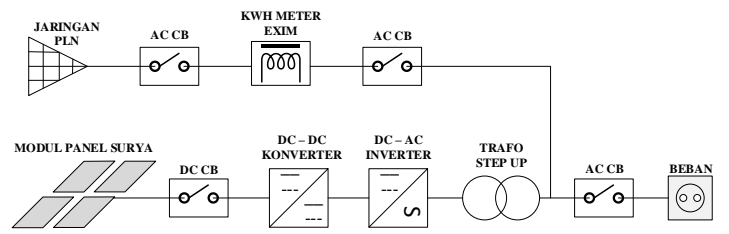

Gambar 2. Sistem Distribusi PLTS On Grid

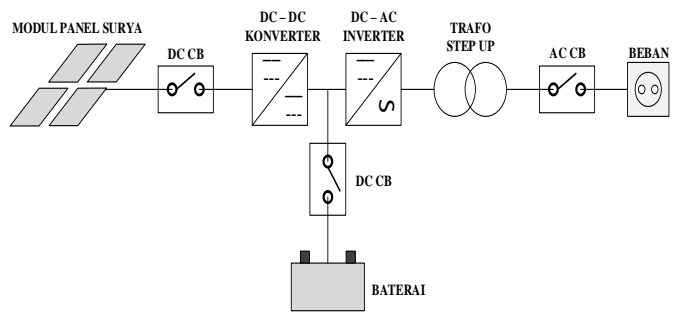

Gambar 3. Sistem Distribusi PLTS Off Grid 


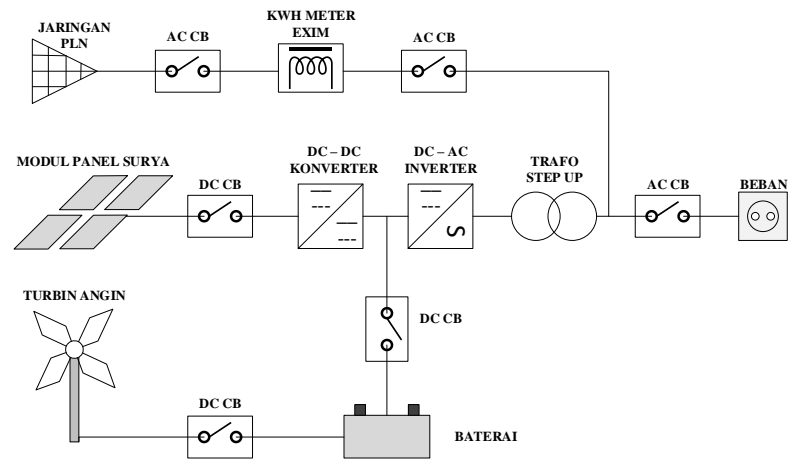

Gambar 4. Sistem Distribusi PLT Hybrid On Grid

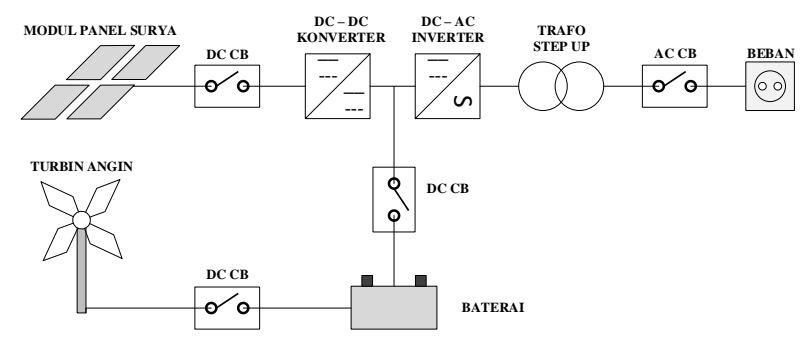

Gambar 5. Sistem Distribusi PLT Hybrid Off Grid

\section{b. Desain Modul Digital}

Untuk mempermudah proses pengemangan bahan ajar ini dibuat struktur alur dan story board dari modul ajar yang akan dibuat. Struktur alur dibuat untuk mempermudah perancangan alur jalannya program pada modul ajar yang akan dikembangkan. Struktur alur dari modul digital yang akan dikembangkan dapat dilihat pada gambar 6.

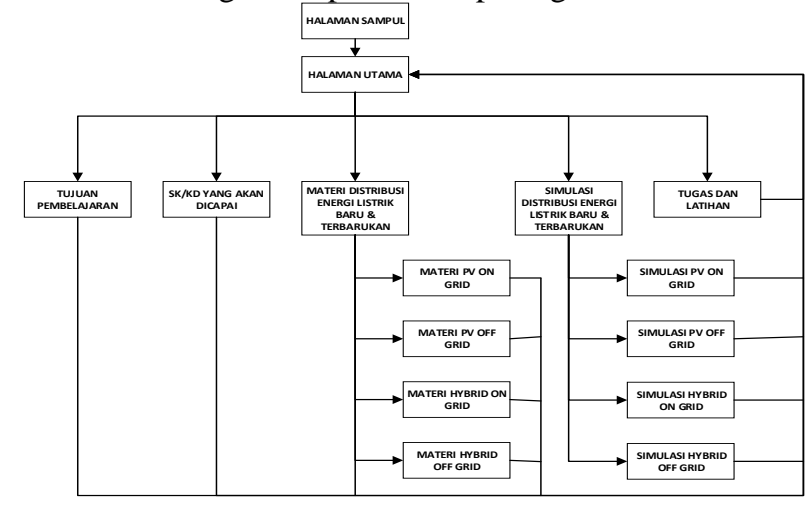

Gambar 6 Struktur Alur Media Pembelajaran

\section{Develop}

Pada tahap pengembangan, setelah desain divalidasi oleh ahli I dan ahli II, dilakukan realisasi desain modul digital dalam bentuk file dengan ekstensi .exe, serta simulator dalam bentuk program single line diagram didalam aplikasi ETAP 12.6.0. Penelitian dan pengembangan media pembelajaran digital sistem distribusi tenaga listrik pada pembangkit listrik energi baru dan terbarukan ini diharapkan kedepannya dapat menunjang proses pembelajaran sehingga tingkat pemahaman mahasiswa lebih baik kedepannya.

\section{Implement}

Pada tahap implementasi ini media pembelajaran digital hasil pengembangan yang sudah divalidasi ahli 1 dan ahli 2 akan diterapkan secara langsung kedalam pembelajaran. Setelah divalidasi maka bisa dipastikan media pembalajaran digital sistem distribusi tenaga listrik pada pembangkit listrik energi baru dan terbarukan dapat digunakan sebagai media pembelajaran. Untuk menguji kelayakan media pembalajaran digital maka dilaksanakan implementasi dengan kegiatan pembelajaran dikelas. Kegiatan implementasi ini dilakukan dengan mempersiapkan modul digital dan simulator sebagai media pembelajaran.

Pada tahap ini media pembalajaran digital sistem distribusi tenaga listrik pada pembangkit listrik energi baru dan terbarukan akan diimplementasikan kepada mahasiwa program studi S1 Teknik Elektro angkatan 2016 dengan konsentrasi arus kuat jurusan Teknik Elektro Universitas Negeri Malang yang sedang menempuh matakuliah Energi Baru dan Terbarukan.

\section{Evaluate}

Evaluasi merupakan proses untuk melihat apakah pada tahapan yang sudah ditempuh dalam 4 (empat) tahapan model ADDIE diatas sudah pada batas kelayakan atau belum. Apabila terdapat kekurangan atau ketidaksesuaian maka akan dilakukan revisi terhadap setiap tahapan tersebut. Hasil dari analisis tersebut kemudian digunakan sebagai bahan pertimbangan untuk mengembangkan suatu produk. Pada tahap desain, evaluasi dilakukan dengan mempertimbangkan pendapat ahli tentang desain yang dikembangkan. Tahap evaluasi juga terdapat pada tahap pengembangan, dilakukan dengan mengembangkan bentuk media pembelajaran. Kemudian pada tahap implementasi, tahap evaluasi dilakukan dengan menilai produk yang dikembangkan, mencari kekurangan yang bisa diperbaiki dan melakukan perbaikan tersebut. Jadi pada setiap tahapan selalu dilakukan evaluasi.

\section{Teknik Validasi dan Uji Coba}

Teknik validasi dan uji coba atau evaluasi produk pada penelitian dan pengembagan ini yaitu nantinya dilakukan dengan 3 (tiga) tahapan yaitu validasi produk oleh ahli, uji coba kelompok kecil dan uji coba kelompok besar. Hasil validasi dan uji coba ini bertujuan untuk mengumpulkan data terkait dan kekurangan bahan ajar. Ketiga tahap tersebut dijelaskan sebagai berikut.

a. Validasi Ahli

Dalam tahapan validasi produk oleh ahli melibatkan 2 (dua) validator yaitu dosen TE UM sebagai reviewer. Evaluasi ini bertujuan untuk menilai kelayakan isi, relevan atau tidaknya isi dengan tujuan pembelajaran, dan kualitas bahan ajar sebelum diuji cobakan kepada peserta didik/ 
mahasiswa. Setelah melakukan validasi produk oleh ahli kemudian produk direvisi terhadap kesalahan-kesalahan yang telah ditemukan. Instrumen pengumpulan data pada evaluasi ini menggunakan angket.

\section{b. Uji Coba Kelompok Kecil}

Evalusai kelompok kecil untuk mengetahui kelayakan media pembalajaran digital sistem distribusi tenaga listrik pada pembangkit listrik energi baru dan terbarukan dengan memilih 10 (sepuluh) mahasiswa S1 TE 2015 yang telah menempuh materi pokok yang terdapat pada standar kompetensi matakuliah Energi Baru dan Terbarukan. Melalui uji coba ini dapat diketahui tingkat kemudahan materi untuk dipahami, sistematis dan menariknya media pembalajaran digital dan mengdentifikasi masalah yang mungkin muncul. Instrumen pengumpulan data pada evaluasi ini menggunakan angket.

\section{c. Uji Coba Kelompok Besar}

Uji coba kelompok besar dilakukan untuk mengetahui kelayakan media pembelajaran yang telah dibuat dengan melibatkan 33 (tiga puluh tiga) mahasiswa S1 TE konsentrasi arus kuat angkatan 2016 dengan berbagai karakteristik. Tujuan evaluasi ini untuk mengetahui kelayakan produk yang. Instrumen pengumpulan data pada evaluasi ini menggunakan angket.

\section{Instrumen Pengumpulan Data}

Instrumen evaluasi untuk uji validitas/kelayakan bahan ajar ini menggunakan angket. Angket uji kelayakan bahan ajar berisi penilaian materi dan penilaian media pembelajaran. Sebelum digunakan, angket validasi bahan ajar divalidasi oleh dosen pembimbing peneliti. Kisi-kisi angket untuk menilai kelayakan materi berpedoman padan Badan Standar Nasional Pendidikan (BSNP) tahun 2006.

Untuk menilai kelayakan materi bahan ajar digunakan 3 (tiga) aspek penilaian berpedoman pada BSNP tahun 2006 yaitu: (1) Aspek kelayakan isi materi; (2) aspek kelayakan penyajian materi; dan (3) aspek kelayakan bahasan materi. Tabel 1 menyebutkan kriteria dari tiap aspek yang dinilai. Tabel 1 Kisi-kisi Instrumen Kelayakan Materi

\begin{tabular}{lll}
\hline Aspek & Kriteria & Sumber \\
\hline Aspek & $\bullet$ Cakupan materi & BSNP \\
Kelayakan Isi & $\bullet$ Akurasi Materi & $(2006)$ \\
& $\bullet$ Kemutakhiran Materi & \\
Aspek & $\bullet$ Mendorong keingintahuan & \\
Kelayakan & $\bullet$ Peknik penyajian & $(2006)$ \\
Penyajian & $\bullet$ Pendukung penyajian pembelajaran & \\
Aspek & $\bullet$ Komunikatif & BSNP \\
Kelaakan & $\bullet$ Koherensi & $(2006)$ \\
Kebahasaan & $\bullet$ Penggunaan istilah dan simbol / &
\end{tabular}

Kisi-kisi instrumen penilaian materi dan media digunakan sebagai pedoman penyusunan angket penelitian. Melalui angket penelitian yang akan diisi oleh validator I, validator II, mahasiswa subjek uji coba kelompok kecil dan mahasiswa uji coba kelompok besar tersebut dapat diketahui kesalahan dari bahan ajar yang telah dikembangkan. Dengan demikian dapat memperbaiki kesalahan agar bahan ajar yang peneliti kembangkan bisa digunakan untuk kegiatan pembelajaran matakuliah Energi Baru dan Terbarukan.

Aspek yang dinilai pada penilaian kelayakan media terdiri dari: (1) aspek kelayakan perangkat lunak; (2) aspek desain pembelajaran; dan (3) aspek komunikasi visual. Kisikisi angket untuk menilai kelayakan media pembelajaran menurut Wahono [5] yang ditunjukan pada Tabel 2.

Tabel 2 Kisi-kisi Instrumen Kelayakan Media

\begin{tabular}{|c|c|c|}
\hline Aspek & Kriteria & Sumber \\
\hline $\begin{array}{l}\text { Kelayakan } \\
\text { Perangkat } \\
\text { Lunak }\end{array}$ & $\begin{array}{l}\text { - Usabilitas (mudah digunakan dan } \\
\text { sederhana dalam } \\
\text { pengoperasiannya). } \\
\text { - Ketepatan pemilihan jenis aplikasi } \\
\text { / software / tool untuk } \\
\text { pengembangan } \\
\text { - Kompatibilitas (media } \\
\text { pembelajaran dapat diinstalasi / } \\
\text { dijalankan di berbagai hardware } \\
\text { dan software yang ada). } \\
\text { - Pemaketan program media } \\
\text { pembelajaran terpadu dan mudah } \\
\text { dalam eksekusi. } \\
\text { Petunjuk penggunaan (user } \\
\text { manual) media pembelajaran } \\
\text { dipaparkan dengan jelas. }\end{array}$ & $\begin{array}{l}\text { Wahono } \\
(2006)\end{array}$ \\
\hline $\begin{array}{l}\text { Aspek Desain } \\
\text { Pembelajaran }\end{array}$ & $\begin{array}{l}\text { - Relevansi tujuan pembelajaran } \\
\text { dengan SK/ KD/ Kurikulum. } \\
\text { - Kontekstualitas dan aktualitas. } \\
\text { - Kesesuaian materi dengan tujuan } \\
\text { pembelajaran. } \\
\text { - Sistematis, runut, alur, logika jelas } \\
\text { - Kejelasan uraian pembahasan } \\
\text { materi, contoh soal, evaluasi. } \\
\text { - Konsistensi evaluasi dengan } \\
\text { tujuan pembelajaran. }\end{array}$ & $\begin{array}{l}\text { Wahono } \\
\text { (2006) }\end{array}$ \\
\hline $\begin{array}{l}\text { Aspek } \\
\text { Komunikasi } \\
\text { Visual }\end{array}$ & $\begin{array}{l}\text { - Sederhana dan memikat. } \\
\text { - Visual (layout design, typography, } \\
\text { warna). } \\
\text { - Layout komunikatif (ikon }\end{array}$ & $\begin{array}{l}\text { Wahono } \\
\text { (2006) }\end{array}$ \\
\hline
\end{tabular}

Pembuatan angket penelitian menggunakan 4 (empat) tingkat penilaian menurut skala Likert. Tabel 3 menunjukan kriteria tingkat peilaian pada angket untuk ahli media, ahli materi dan mahasiswa dengan menggunakan skala likert Sugiyono [6].

Tabel 3 Skala Likert

\begin{tabular}{cl}
\hline Skor & \multicolumn{1}{c}{ Keterangan } \\
\hline 4 & $\begin{array}{l}\text { Apabila responden memberikan penilaian Sangat } \\
\text { Baik/Sangat Layak/Sangat Menarik/Sangat Mudah/Sangat } \\
\text { Sesuai/Sangat Tepat. }\end{array}$ \\
& $\begin{array}{l}\text { Apabila responden memberikan penilaian } \\
\text { Baik/Layak/Menarik/Mudah/Sesuai/Tepat. }\end{array}$
\end{tabular}

2 Apabila responden memberikan penilaian Cukup 


\section{Analisis Data}

Jenis data yang diperoleh dari penelitian pengembangan laboratorium virtual ini berupa data kualitatif dan kuantitatif. Data kualitatif berupa tanggapan, komentar, kritik, saran dan rekomendasi tentang laboratorium virtual oleh validator I, validator II dan mahasiswa subjek uji coba yang ditulis dikotak saran pada lembar akhir angket validasi bahan ajar. Sedangkan data kuantitatif diperoleh dari skor angket yang diberikan oleh subjek uji coba.

Untuk mengetahui kelayakan laboratorium virtual yang dikembangkan yaitu dengan melakukan evaluasi atau uji coba. Langkah awal dengan cara mencari nilai persentase skor yang diperoleh melalui hasil angket uji validasi bahan ajar, yaitu dengan rumus 1 .

$$
\begin{aligned}
& V=\frac{T s e}{T s h} \times 100 \% \\
& \text { Keterangan: } \\
& \text { V = Validitas (Kelayakan) } \\
& \text { Tse = Total skor empirik } \\
& \text { Tsh = Total skor maksimal yang diharapkan }
\end{aligned}
$$

Setelah mengetahui hasil persentase angket tersebut, kemudian melakukan pengelompokan kedalam kriteria kelayakan bahan ajar yang ditunjukan oleh Tabel 4 .

Tabel 4 Kriteria Kelayakan

\begin{tabular}{lll}
\hline No. & Skala Nilai (100\%) & Keterangan \\
\hline 1. & $85,01 \%-100,00 \%$ & $\begin{array}{l}\text { Sangat valid, atau dapat } \\
\text { digunakan tanpa revisi. }\end{array}$ \\
2. & $70,01 \%-85,00 \%$ & $\begin{array}{l}\text { Cukup valid, atau dapat } \\
\text { digunakan namun perlu revisi } \\
\text { kecil. }\end{array}$ \\
3. & $50,01 \%-70,00 \%$ & $\begin{array}{l}\text { Kurang valid, disarankan tidak } \\
\text { dipergunakan, perlu relu revisi } \\
\text { besar. }\end{array}$
\end{tabular}

\section{HASIL DAN PEMBAHASAN}

\section{Hasil Pembuatan Produk}

Hasil pengembangan produk ini berupa bahan ajar matakuliah Energi Baru dan Terbarukan untuk mahasiswa S1 TE UM konsentrasi arus kuat. Topik yang dibahas dalam bahan ajar ini adalah: (a) sistem distribusi energi listrik baru terbarukan on grid; (b) sistem distribusi energi listrik baru terbarukan off grid; (c) sistem distribusi energi listrik baru terbarukan hybrid on grid; dan (d) sistem distribusi energi listrik baru terbarukan hybrid off grid. Media pembelajaran digital yang dikembangkan file dengan ekstensi .exe yang bisa digunakan sebagai bahan ajar baik di dalam perkuliahan maupun digunakan sebagai sarana belajar mandiri.
Setelah bahan ajar selesai dibuat, selanjutnya dilakukan validasi produk oleh 2 (dua) dosen TE UM yang berkompeten untuk mengetahui validitas bahan ajar sistem distribusi energi listrik baru dan terbarukan. Salah satu dari 2 (dua) dosen tersebut merupakan dosen yang pernah mengampu matakuliah Energi Baru dan Terbarukan, Sistem Transmisi \& Distribusi dan Sistem Proteksi. Sedangkan dosen satu lagi merupakan dosen yang berkompetensi di bidang pendidikan.

Setelah melewati tahap validasi produk oleh ahli, dilanjutkan tahap uji coba produk pada kelompok kecil yang melibatkan 10 (sepuluh) mahasiswa S1 TE 2015 konsentrasi arus kuat yang sudah menempuh matakuliah Energi Baru dan Terbarukan. 10 (sepuluh) Mahasiswa S1 TE 2015 konsentrasi arus kuat tersebut akan menggunakan media pembelajaran digital yang dikembangkan oleh peneliti, selanjutnya mahasiswa tersebut mengisi angket penelitian. Melalui angket penelitian tersebut peneliti bisa mengetahui tingkat kelayakan produk yang dikembangkan.

Uji coba selanjutnya adalah uji coba kelompok besar yang melibatkan 33 (tiga puluh tiga) mahasiswa S1 TE 2016 konsentrasi arus kuat. Pada tahap ini dilakukan demontrasi pembelajaran menggunakan media pembelajaran digital yang telah dikembangkan. Setelah itu mahasiswa mengisi angket untuk mengetahui tingkat kelayakan media dan respon mahasiswa setelah menggunakan media pembelajaran digital yang telah dikemangkan.

\section{Tampilan Antarmuka Media Pembelajaran Digital}

a. Halaman Beranda

Halaman ini berisi informasi umum terkait media pembelajaran yang dikembangkan berupa penanda waktu, judul media pembelajaran, logo universitas dan petunjuk awal navigasi media. Selain itu terdapat beberapa icon navigasi untuk mengoperasikan media pembelajaran seperti icon menu untuk mengakses berbagai konten yang terdapat didalam media pembelajaran digital, icon windows untuk mengatur ukuran media pembelajaran digital, icon close untuk menutup program media pembelajaran digital, serta icon navigasi untuk mengatur musik pengiring media pembelajaran digital.

b. Side Slide Menu

Side slide menu merupakan menu yang akan tampil dari samping layer media pembelajaran digital ketika tombol navigasi menu ditekan. Menu-meu tersebut antara lain menu beranda, panduan, kompetensi, materi, simulasi, evaluasi dan profil pengembang.

c. Halaman Panduan

Halaman ini berisi panduan singat mengenai fungsi dari beberapa icon yan terdapat dalam media pembelajaran digital sehingga akan memudahkan pengguna dalam menjalankan aplikasi media pembelajaran. Selain itu juga terdapat panduan penggunaan bagi mahasiswa dan dosen yang digunakan sebagai pedoman pengguna saat menggunakan media pembelajaran digital.

d. Halaman Kompetensi 
Halaman kompetensi berisi informasi dari kompetensi keahlian yang akan dicapai menggunakan media pembelajaran digital ini. Selain dari kompetensi keahlian, juga terdapat indikator dan tujuan pembelajaran menggunakan media pembelajaran digital ini. Halaman indikator dan tujuan dapat dilihat dengan menekan icon arah panah kekanan pada sisi kanan layer jendela media pembelajaran digital.

e. Halaman Materi

Saat memasuki halaman materi, pengguna media pembelajaran digital akan disuguhi dengan pilihan materi tentang sistem distribusi energi listrik baru dan terbarukan. Beberapa pilihan bahasan materi yang disajikan yaitu: (1) Pendahuluan, didalamnya terdapat materi dasar tentang perencanaan instalasi PLTS; (2) PLTS Sistem Off Grid; (3) PLTS Sistem On Grid; (4) PLT Hybrid Sistem Off Grid; dan (5) PLT Hybrid Sistem Off Grid. Materi yang yang akan dibahas pada media pembelajaran digital tersebut sudah disesuaikan dengan tujuan yang hendak dicapai pada pembelajaran dengan menggunakan media pembelajaran digital ini.

f. Halaman Simulasi

Halaman simulasi berisi panduan pelaksanaan simulasi dari setiap materi yang dipelajari pada media pembelajaran digital dengan menggunakan aplikasi ETAP 12.6.0. Penyajian materi panduan simulasi dilakukan dengan bertahap, pada setiap tahapnya panduan yang diberikan akan semakin berkurang dan terbatas. Hal ini dimaksudkan agar mahasiswa setiap melanjutkan pada praktikum selanjutnya, mahasiswa dipaksa untuk semakin berfikir dan melatih dirinya mengoperasikan aplikasi ETAP 12.6.0. Selain panduan dalam melaksanakan simulasi, juga terdapat latihan agar mahasiswa lebih memahami materi yang dipelajari.

g. Halaman Evaluasi

Pada pembukaan halaman evaluasi terdapat informasi singkat mengenai evaluasi yan akan dikerjakan dan tombol untuk memulai mengerjakan. Halaman evaluasi terdiri dari 10 (sepuluh) soal pilihan ganda yang masing-masing soal bernilai 10 poin. Apabila mahasiswa menjawab soal dengan benar, maka secara otomatis kolom nilai akan memberi bertambah sejumlah 10 poin dan tidak akan berubah apabila jawaban yang diberikan salah.

h. Halaman Profil

Halaman profil pengembang berisi informasi singkat tentang pengembang media pembelajaran digital sistem distribusi energi listrik baru dan terbarukan. informasi yang terdapat pada halaman profil ini meliputi nama, alamat, jenjang Pendidikan dan beberapa kontak yang dapat dihubungi.

\section{Hasil Uji Kelayakan Bahan Ajar}

Penyajian data dalam penelitian ini terdiri dari data: (1) hasil uji coba perseorangan; (2) hasil uji coba kelompok kecil; dan (3) hasil uji coba kelompok besar. Uji coba perseorangan dilakukan oleh 2 (dua) validator ahli yaitu dosen TE UM untuk menguji kelayakan bahan ajar. Sedangkan uji coba kelompok kecil dilakukan oleh 10

(sepuluh) mahahsiswa S1 TE 2015 dengan konsentrasi arus kuat yang sudah menempuh mata kuliah Energi Baru dan Terbarukan pada semester sebelumnya, uji coba ini dilakukan untuk melihat seberapa layak media pembelajaran digital yang telah divalidasi oleh ahli dan diperbaiki sesuai dengan saran dari ahli. Uji coba terakhir yaitu uji coba kelompok besar yang bertujuan mengetahui tingkat keefektifan bahan ajar ketika digunakan dalama kegiatan pembelajaran. Subjek penelitian pada uji coba kelompok besar adalah mahasiswa S1 TE 2016 konsentrasi arus kuat. Berikut penjabaran dari masing-masing data uji coba yang telah dilakukan.

Tabel 5 Hasil Validasi Ahli I

\begin{tabular}{|c|c|c|c|c|c|}
\hline No. & $\begin{array}{c}\text { Aspek } \\
\text { Penilaian }\end{array}$ & Tse & Tsh & $\%$ & Keterangan \\
\hline 1 & Kelayakan Isi & 36 & 44 & $81,8 \%$ & Cukup Valid \\
\hline 2 & $\begin{array}{l}\text { Kelayakan } \\
\text { Penyajian }\end{array}$ & 22 & 28 & $78,6 \%$ & Cukup Valid \\
\hline 3 & $\begin{array}{l}\text { Kelayakan } \\
\text { Kebahasaan }\end{array}$ & 16 & 20 & $80,0 \%$ & Cukup Valid \\
\hline 4 & $\begin{array}{l}\text { Kelayakan } \\
\text { Perangkat } \\
\text { Lunak }\end{array}$ & 24 & 28 & $85,7 \%$ & Sangat Valid \\
\hline 5 & $\begin{array}{l}\text { Kelayakan } \\
\text { Desain }\end{array}$ & 21 & 24 & $87,5 \%$ & Sangat Valid \\
\hline 6 & $\begin{array}{l}\text { Kelayakan } \\
\text { Komunikasi } \\
\text { Visual }\end{array}$ & 25 & 28 & $89,3 \%$ & Sangat Valid \\
\hline Rata & rata & & & $83,72 \%$ & Cukup Valid \\
\hline
\end{tabular}

Tabel 6 Hasil Validasi Ahli II

\begin{tabular}{clcccc}
\hline No. & \multicolumn{1}{c}{$\begin{array}{c}\text { Aspek } \\
\text { Penilaian }\end{array}$} & Tse & Tsh & \% & Keterangan \\
\hline $\mathbf{1}$ & Kelayakan Isi & 37 & 44 & $84,1 \%$ & Cukup Valid \\
$\mathbf{2}$ & $\begin{array}{l}\text { Kelayakan } \\
\text { Penyajian }\end{array}$ & 22 & 28 & $78,6 \%$ & Cukup Valid \\
$\mathbf{3}$ & $\begin{array}{l}\text { Kelayakan } \\
\text { Kebahasaan }\end{array}$ & 16 & 20 & $80,0 \%$ & Cukup Valid \\
$\mathbf{4}$ & $\begin{array}{l}\text { Kelayakan } \\
\text { Perangkat }\end{array}$ & 24 & 28 & $85,7 \%$ & Sangat Valid \\
& $\begin{array}{l}\text { Lunak } \\
\text { Kelayakan }\end{array}$ & 19 & 24 & $79,2 \%$ & Cukup Valid \\
$\mathbf{6}$ & $\begin{array}{l}\text { Desain } \\
\text { Kelayakan }\end{array}$ & 25 & 28 & $89,3 \%$ & Sangat Valid \\
Komunikasi & & & &
\end{tabular}


Pengembangan Media Pembelajaran Digital Sistem Distribusi Enerdi Listrik

Tabel 7 Hasil Uji Kelompok Kecil

\begin{tabular}{|c|c|c|c|c|c|}
\hline No. & $\begin{array}{c}\text { Aspek } \\
\text { Penilaian }\end{array}$ & Tse & Tsh & $\%$ & Keterangan \\
\hline 1 & Kelayakan Isi & 386 & 440 & $87,7 \%$ & Sangat Valid \\
\hline 2 & $\begin{array}{l}\text { Kelayakan } \\
\text { Penyajian }\end{array}$ & 241 & 280 & $86,1 \%$ & Sangat Valid \\
\hline 3 & $\begin{array}{l}\text { Kelayakan } \\
\text { Kebahasaan }\end{array}$ & 165 & 200 & $82,5 \%$ & Cukup Valid \\
\hline 4 & $\begin{array}{l}\text { Kelayakan } \\
\text { Perangkat } \\
\text { Lunak }\end{array}$ & 241 & 280 & $86,1 \%$ & Sangat Valid \\
\hline 5 & $\begin{array}{l}\text { Kelayakan } \\
\text { Desain }\end{array}$ & 208 & 240 & $86,7 \%$ & Sangat Valid \\
\hline 6 & $\begin{array}{l}\text { Kelayakan } \\
\text { Komunikasi }\end{array}$ & 237 & 280 & $84,6 \%$ & Cukup Valid \\
\hline
\end{tabular}

Tabel 8 Hasil Uji Kelompok Besar

\begin{tabular}{clcccc}
\hline No. & \multicolumn{1}{c}{$\begin{array}{c}\text { Aspek } \\
\text { Penilaian }\end{array}$} & Tse & Tsh & \% & Keterangan \\
\hline $\mathbf{1}$ & $\begin{array}{l}\text { Kelayakan } \\
\text { Isi }\end{array}$ & 1272 & 1452 & $87,6 \%$ & Sangat Valid \\
$\mathbf{2}$ & $\begin{array}{l}\text { Kelayakan } \\
\text { Penyajian } \\
\mathbf{3}\end{array}$ & 810 & 924 & $87,7 \%$ & Sangat Valid \\
& $\begin{array}{l}\text { Kelayakan } \\
\text { Kebahasaan } \\
\mathbf{4}\end{array}$ & 576 & 660 & $87,3 \%$ & Sangat Valid \\
& $\begin{array}{l}\text { Kelayakan } \\
\text { Perangkat }\end{array}$ & 816 & 924 & $88,3 \%$ & Sangat Valid \\
& $\begin{array}{l}\text { Lunak } \\
\text { Kelayakan }\end{array}$ & 703 & 792 & $88,8 \%$ & Sangat Valid \\
& $\begin{array}{l}\text { Desain } \\
\text { Kelayakan }\end{array}$ & 822 & 924 & $89,0 \%$ & Sangat Valid \\
& $\begin{array}{l}\text { Komunikasi } \\
\text { Visual }\end{array}$ & & & & \\
\hline Rata-rata & & & $88 \%$ & Sangat Valid \\
\hline
\end{tabular}

Berdasarkan data yang diperoleh, maka hasil akhir persentase kelayakan untuk validasi oleh ahli sebesar $83,4 \%$ diperoleh rata-rata persentase dari validator I dan validator II.

Hasil akhir persentase kelayakan pada uji coba kelompok kecil sebesar $86 \%$ dan yang terakhir rata-rata persentase kelayakan dari hasil uji coba kelompok besar sebesar $88 \%$.

Dari keseluruhan data uji coba tersebut dapat digambarkan dengan grafik persentase seperti ditunjukan pada Gambar 7.

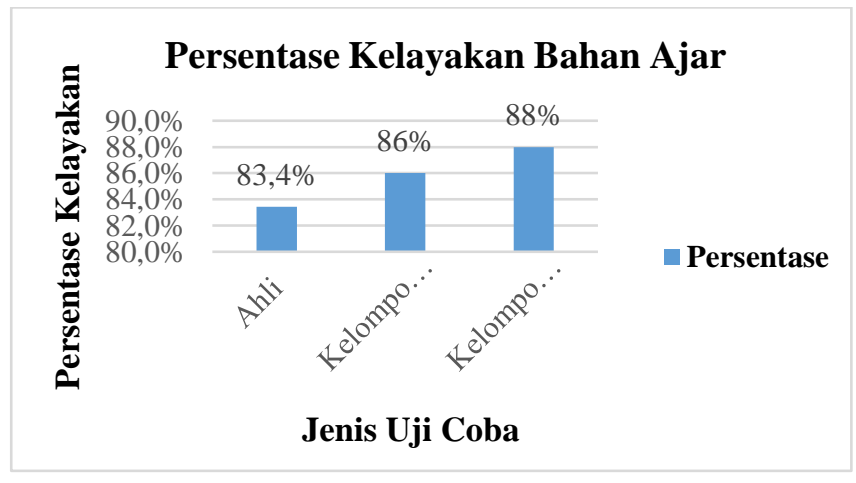

Gambar 7. Grafik Hasil Uji Kelayakan

\section{PENUTUP}

Penelitian dan pengembangan bahan ajar ini menggunakan model pengembangan ADDIE yang memiliki 5 (lima) tahapan yaitu: (1) Analysis; (2) Design; (3) Develop; (4) Implement; dan (5) Evaluate. Berdasakan hasil uji kelayakan oleh validator I dan II bahan ajar dinyatakan valid namun perlu direvisi dengan tingkat kelayakan 83,4\%. Sedangkan berdasarkan hasil uji coba kelompok kecil, media pembelajaran digital dinyatakan valid $86 \%$ atau layak tanpa ada revisi ulang. Dan terakhir untuk hasil uji coba kelompok besar media pembelajaran digital dinyatakan valid $88 \%$ atau layak tanpa ada revisi. Jadi kesimpulannya media pembelajaran layak untuk diimplementasikan pada pembelajaran.

\section{DAFTAR PUSTAKA}

[1] Anonim, "Statistik Energi Baru Terbarukan dan Konversi Energi (EBTKE)," Jakarta: ESDM, 2016.

[2] Anonim, "Energi Baru dan Terbarukan Untuk Menjaga Bauran Energi Pembangki,” Jakarta: ESDM, 2018.

[3] Kamus Besar Bahasa Indonesia (KBBI). (Online), (http://kbbi-web-id.cdn.ampproject.org/), diakses 20 Desember 2019.

[4] Smith, S dan Sandra K., "Assessing and Addressing Student Science Ideas. Jurna Pendidikan," (Online), (http://ro.ecu.au/ajte/vol45/iss4/4), 2008. Diakses 5 Januari 2019. 
Indonesian Journal of Electrical and Electronics Engineering. Volume 02 Nomor 02 Tahun 2019, 48-52

[5] Wahono RS., "Aspek dan Kriteria Media Pembelajaran,” (Online), (http://romistriawahono.net), 2006. Diakses 9 Januari 2019.

[6] Sugiyono, "Metode Penelitian Pendidikan Kuantitatif, Kualitatif dan R\&D,” Bandung: Alfabeta, 2016. 